\title{
Differentiation Policy and Access to Higher Education in Northern Ontario, Canada:An Analysis of Unintended Consequences
}

\author{
Roger Pizarro Milian \\ University of Toronto \\ Brad Seward \\ University of Toronto \\ David Zarifa \\ Nipissing University
}

\begin{abstract}
Differentiation policies have been implemented in Ontario higher education $(\mathrm{HE})$ with the intent of manufacturing a more efficient and higherquality system. Policy-makers have repeatedly touted their benefits, but the unintended consequences of differentiation policies remain neglected. Through this piece, we present a northern critique of differentiation policies grounded on the distance deterrence effects literature. We propose that differentiation policies threaten to exacerbate existing provincial north-south disparities in $\mathrm{HE}$ access, hampering human capital formation and economic development in northern communities. In addition, we specify some strategies to mitigate these detrimental effects and conclude by providing a conceptual framework through which to understand regional "blind spots" in differentiation policy.
\end{abstract}




\section{Introduction}

In Ontario, Canada, differentiation has been contemplated as a strategy to improve the quality and efficiency of higher education (HE) since at least the 1960s (Piche, 2014; Piche \& Jones, 2016; Pizarro Milian et al., 2016; Skolnik, 2013). Local policy-makers and analysts have repeatedly argued that, by focusing institutional resources and attention toward existing areas of strength, colleges and universities should be capable of achieving higher quality than if they continued as "generalists," servicing a smorgasbord of program areas (e.g., Weingarten \& Deller, 2010). At the system level, institutional specialization has been depicted as a tool to reduce unnecessary program duplication and budget expenditures, while allowing students access to a variety of study options (e.g., Rae, 2005). Though these benefits of differentiation are widely extolled, few commentators have considered the prospective problems and unintended consequences of these policies. In previous work (Pizarro Milian et al., 2016; Pizarro Milian, 2018), colleagues and I have drawn on insights from the field of organizational studies to address the former at some length, demonstrating how institutional forces may hamper the implementation of differentiation policies. In this current piece, we shift our focus to the latter topic, outlining some of the unexpected effects of differentiation policies on access to $\mathrm{HE}$ in the northern region of Ontario-an issue that has been generally neglected by both academics and policy-makers.

This analysis builds on the long tradition of examining the "latent" functions (Merton, 1936) or "unintended" functions (Boudon, 1977) of social action and structures within social science research. It is also grounded in the distance deterrence literature (e.g., Sa et al., 2004; 2006), which has demonstrated the impact of geographical proximity on institutional choice (Frenette, 2004; Zarifa et al., 2018); field of study selection (Hango et al., 2019; Grossmann et al., 2015; Suhonen, 2014); and broader skills development (Zarifa et al., 2019). On such a foundation, we mount the argument that greater institutional specialization will adversely impact residents in Northern Ontario through limiting their educational achievement. In place of more specialized colleges and universities, we advance that equitable access to $\mathrm{HE}$ in Northern Ontario is best served 
through the augmentation of program offerings, and the presence of "generalist" colleges and universities. Despite said recommendationand in light of the provincial government's ongoing commitment to pursuing differentiation - we identify some strategies to help mitigate the potentially negative impacts of these policies on the Provincial North. We conclude by taking a higher-level view of the situation, and theorizing how policies like differentiation reflect an ongoing urban bias in Canadian HE policy-making that often has harmful effects on peripheral northern communities.

\section{Differentiation in Ontario HE Policy (2005-present)}

Several recent peer-reviewed articles and dissertations have documented the history of differentiation within Ontario HE policy in extensive detail (e.g., Piche, 2014, p. 4-22; Piche, 2016; Pizarro Milian et al., 2016; Pizarro Milian, 2018). We refrain from repeating this labour-intensive exercise here, choosing instead to provide an expedited recap of said policies tailored for international readers who are not familiar with the peculiarities of the Ontario context.

After a period of dormancy, the idea of differentiation was revived in Ontario in 2005, through what is locally referred to as the "Rae Report" (Cameron, 2005; Clark \& Trick, 2006; Lennon et al., 2015; Skolnik 2013). This provincial policy document lamented that Ontario had "a large, mature system without a sufficiently clear sense of purpose and without enough money to do the job" (Rae, 2005, p. 9). In turn, it recommended that the provincial government should "encourage the distinct evolution of each institution and promote differentiation through the tuition framework, accountability arrangements and the design of the province's funding formula" (p. 29). The intent and local rationalization of this strategy paralleled that witnessed in other jurisdictions (see Bastedo, 2009; Bastedo \& Gumport, 2003; Huisman, 1998). By orienting their attention and resources toward particular program and functional areas (e.g., teaching or research), each institution was depicted as capable of achieving greater distinction in their "niche," elevating the quality of the education they could offer to prospective students (see Rae, 2005, p. 87, 104). 
Over the next decade, the Rae Report sparked a tidal wave of interest in how differentiation could best be leveraged to improve $\mathrm{HE}$ in the province. Jones \& Skolnik's (2009) early commentary suggested that while a more specialized set of colleges and universities certainly had its drawbacks, it allowed the system to "exploit potential complementarities among the specific disciplines and subjects covered" (p. 7). Weingarten \& Deller (2010, p. 10) also persuasively argued that local universities should be prompted to specialize in pre-existing areas of strength, referring to both programmatic (e.g., field of study) and functional areas of specialization. ${ }^{1}$

In 2013, growing support for differentiation as a policy strategy resulted in the publication of Ontario's Differentiation Policy Framework for Post-secondary Education. Therein, it was argued that the Great Recession made it unfeasible for the province to make any significant investments in $\mathrm{HE}$ in the foreseeable future. Within this context of budgetary constraints, differentiation was presented as a strategy through which to prompt system improvements in the absence of capital investments. Greater alignment between $\mathrm{HE}$ institutions and their surrounding communities was depicted as a critical factor that should inform specialization, as a tighter linkage would ensure that students "graduate with skills that respond to local and provincial labour market needs and contribute to social development" (p. 10). ${ }^{2}$ Following the publication of this framework, colleges and universities worked with the province to produce Strategic Mandate Agreements, which explicitly and publicly outlined their areas of strength, along with long-term goals and indicators for progress toward differentiation (Auld \& Coates, 2018, p. 26).

Since 2013, the Higher Education Quality Council of Ontario (HEQCO), an agency of the provincial government, has achieved thought leadership on the topic of differentiation through a series of thoughtprovoking reports on the subject (e.g., Hicks et al., 2013; Hicks \& Jonker, 2016; Jonker \& Hicks, 2014; Kaufman et al., 2018; Trick, 2015). The efficiency argument across many of these reports is highly consistent. Hicks \& Jonker (2016) note that differentiation should "leverage and concentrate institutional strengths ... and avoid expensive duplication of effort and services across the 20 universities and 24 colleges" (Hicks \& Jonker, 2016, p. 7). Kaufman, Jonker \& Hicks (2018) have also outlined that "differentiation can eliminate duplication of effort, direct the effective 
allocation of resources, and contribute to the efficient and responsible use of public funds" (p. 3). Similar arguments are made in Hicks et al. (2013). Commenting on the college sector, they point out that "unrealized opportunities" exist for institutions to plan around each other's specialty programs in order to avoid "unsustainable duplication of expertise and infrastructure" (p. 18). Far from unique, however, this argument mirrors similar efficiency-maximizing arguments made in other jurisdictions in previous decades (see Huisman \& Morphew, 1998). As Fallis (2013, p. 54) observes, a desire to offer affordable education often serves as the subtext for differentiation policies. ${ }^{3}$

At the time of writing, differentiation policy has promoted only modest change in the system, arguably due to a combination of intense inertial pressures within the field (Pizarro Milian et al., 2016) and the weak enforcement mechanisms employed by the province (Pizarro Milian, 2018). However, with the election of a new Conservative provincial government in 2018, this may change. The Conservative government has made public its plan to shift $60 \%$ of institutional funding toward performance-based metrics by $2024-25$, up from a tiny $1.4 \%$ previously distributed, based on such metrics in 2018-19 (HEQCO, 2019). In doing so, Ontario has followed the path of other systems that have embraced performance-based funding systems to drive differentiation (see Sörlin, 2007). This shift will place significantly more pressure on both colleges and universities to respond to Ministry mandates over the near future. Few details exist on the actual structure of the new funding arrangements at the time of writing.

\section{Critiques of Differentiation Policy}

Academics have been mute on the unintended effects of differentiation policies on northern communities. ${ }^{4}$ Commentary of this sort has come mostly from advocacy groups. The Canadian Federation of Students (2017), Ontario Graduate Student Alliance (2015), and Ontario Confederation of University Faculty Associations (2013) have each outlined that the move towards specialization could disproportionately impact particular populations, such as Indigenous, northern, and rural students who may experience greater difficulty relocating to enrol in 
HE. The Ontario Undergraduate Student Alliance (2016) has further emphasized that additional supports will be needed to ensure that students from northern communities "maintain a broader accessibility to the higher sector without being negatively impacted by continued movements toward institutional differentiation" (p. 10). The Ontario Public Sector Employees Union (2016) has also argued that differentiation may force out-migration from northern communities, prompting adverse effects on their economic development.

Young, Piche, \& Jones' (2017) report on differentiation and student mobility is the only commentary on this issue that we are aware of that originates from the academic or policy community. The authors acknowledge that geographical inaccessibility can negate the proposed benefits of differentiation and, like the Ontario Undergraduate Student Alliance (2016), argue that targeted funding is needed to ensure that students have equitable access to distant program offerings. However, their treatment of this topic is done mainly in passing, commanding only a few sentences of their entire report. Indeed, it entirely neglects other factors, beyond economic costs, which research shows render long-range student transitions arduous. Their analysis is disconnected from vast international literature examining distance deterrence effects in $\mathrm{HE}$.

The limited commentary on this subject by local academics and policy researchers has left the unintended consequences of differentiation policy on northern students and communities insufficiently considered. Indeed, there remain unrealized opportunities to leverage distance deterrence research (e.g., Sa et al., 2004; 2006) to forecast the unintended effects that differentiation policy will have on these entities. Such an exercise can, in turn, inform the redesign or "tailoring" of differentiation policies to mitigate their consequences.

\section{Towards a Northern Perspective on Differentiation Policy}

Northern Ontario is a vast geographical region that covers roughly 800,000 square kilometres - approximately $90 \%$ of the province's total land mass (Robinson, 2015). It is similar in size to countries such as Chile, Mozambique, and Pakistan. Dispersed across this region are over 150 municipalities, along with a litany of sparsely populated communities (Government of Canada, 2018). Figures from the 2016 Canadian Census 
indicate that roughly 730,000 people reside across this vast space (Rural Ontario Institute, 2017).

At the time of writing, Northern Ontario residents are serviced by a group of six community colleges and four universities clustered primarily around the four northern cities of North Bay, Thunder Bay, Sault Ste. Marie, and Sudbury. ${ }^{5}$ This small number of HE institutions, relative to the total land mass of the region and its highly dispersed population, renders residents in Northern Ontario sensitive to fluctuations in the supply of programs offered by their most proximate institution. Finding a replacement for a locally eliminated program can entail significant travel for northern residents. In an extreme hypothetical case, a resident of Thunder Bay, Ontario, would have to relocate approximately 700 kilometres away from home to enrol at Algoma University (Sault Ste. Marie), the most proximate English-language university, if their program was no longer offered locally at Lakehead University. Travelling to the Greater Toronto Area to enrol in one of its many universities would add another 700 kilometres to that relocation. By comparison, a student in downtown Toronto, finding themselves in a similar scenario, would have an abundance of options within commuting-if not walking-distance. ${ }^{6}$

The spatial dynamic outlined through the hypotheticals above would be unproblematic if students were able to move unimpeded across the province to enrol in their programs of choice. However, studies dating back to the 1960s (e.g., Kariel, 1968; Ullis \& Knowles, 1975) have repeatedly proven that geographical distance shapes student trajectories. This is a finding that has proven remarkably robust at the HE level, having been replicated in a series of studies both within Canada (Frenette, 2004, 2006, 2009; Newbold \& Brown, 2015), and abroad, in countries like Australia (Parker et al., 2016); England (Dickerson \& McIntosh, 2013; Gibbons \& Vignoles, 2012; Gill et al., 2018); Italy (Agasisti \& Dal Bianco, 2007); Germany (Spiess and Wrohlich, 2010; Weßling \& Bechler, 2019); the Netherlands (Bertrand-Cloodt et al., 2010; Sa et al., 2004; 2006); Sweden (Kjellström \& Regnér, 1999); and the United States (Alm \& Winters, 2009; Hugh \& Morgan, 1984; Jepsen \& Montgomery, 2008; Kyung, 1996). It has also been observed at the $K-12$ level across several nations (e.g., Bertrand-Cloodt et al., 2010). All other things being equal, the further a student resides from an institution offering a program, the less likely they are to enrol in it (e.g., Grossmann et al., 2015; Suhonen, 2014; 
Hango et al., 2019). This effect is particularly acute for low-SES groups (e.g., Cullinan et al., 2013; Flannery \& Cullinan, 2013; Long, 2004).

A host of mechanisms contribute to the distance deterrence effects documented in the literature cited above, including financial and psychological costs, along with the availability of information. First, leaving home to pursue $\mathrm{HE}$ entails taking on subsistence costs (e.g., rent, groceries) that would normally be shouldered by the broader family unit if a student remained at home (Cullinan et al., 2013; Pigini \& Staffolani, 2016). These costs can be particularly burdensome for students from lower-SES families, given their inability to tap into family savings set aside for their education (see Kim, et al., 2018). This cost factor is one that has primarily captivated the attention of the advocacy groups (OCUFA, 2013; OUSA, 2016) and other commentators (Young et al., 2017) discussed above. However, out of all the factors complicating long-range transitions, it is the most easily addressed through policy-making via the provision of additional targeted funding.

Other factors are far less amenable to policy intervention. For example, the psychological toll of out-migration on students leaving northern rural communities, in particular, can be extreme (Leppel, 1993; Corbett, 2005; Gibbons \& Vignoles 2012). The "social attachment" (Barcus \& Brun 2009; 2010; Haartsen \& Stockdale, 2018) this group has toward their community can render out-migration analogous to betraying one's family or community (Kloep et al., 2003). These pressures are magnified for ethnic groups with cultural norms that assign youth responsibility for caring for elderly or infant family members (Ruiz, 2007; Smith-Morris et al., 2013). Lastly, as Leppel (1993) notes, information about a college or university weakens with distance. A high school guidance counsellor, for example, will be more familiar with proximate $\mathrm{HE}$ options than those located in far-off locations. Institutions are also less likely to have recruiters targeting distant and sparsely populated communities that constitute small segments of the student market. This has the effect of truncating students' awareness of options in distant locales.

These factors discussed above coalesce to create substantial barriers to $\mathrm{HE}$ participation for northern students under present conditions and would become even more formidable within a more differentiated $\mathrm{HE}$ system. In the latter, students would, by necessity, need to migrate to attend 
their program of choice or adjust their aspirations to remain close to home. Below, we outline these prospective outcomes in greater detail to forecast some of the unintended effects of differentiation policies on Northern Ontario.

\section{Forecasting Effects of Differentiation on Northern Ontario:}

Below, we describe several plausible scenarios for northern students faced with the elimination of local programs within a more differentiated system. One underlying assumption from the economic literature on program choice informs our discussion: beyond geographical proximity, program selection is guided by students' perceptions of the future labour market returns to specific programs (see Alon \& Diprete, 2015; Arcidiacono et al., 2012; Wiswall \& Zafar, 2011). ${ }^{7}$ Through considering the hypothetical scenarios below, we believe it is possible to anticipate some of the potentially harmful effects of differentiation on both northern students and their communities.

\section{Scenario 1: Within HE System Adaptations}

In one plausible scenario, the local elimination of a program may drive students to compromise and stay close to home, moving laterally into second-choice programs offered locally by their first-choice institution. Thus, a hypothetical student interested in a university-level degree within a professional field (e.g., engineering, nursing) that is eliminated locally, may choose to major instead in a discipline within the humanities or social sciences, or vice versa. ${ }^{8}$ Alternatively, they may move vertically, choosing to enrol in a program within their preferred field of study, but at a lower credential level within a local community college. In such scenariosassuming that students initially ranked and chose programs and training based on their expected economic returns, as is often done within the economics of education (Beffy et al., 2012)—students may be driven to make less than optimal human capital investments, relative to those they would have made in the absence of program eliminations. This could subsequently hurt the economic returns they can achieve upon labour market entry, as well as the alignment between labour supply and demand in northern regions. ${ }^{9}$ 
One obvious counterpoint to the scenario outlined above would be that, if northern $\mathrm{HE}$ organizations specialize only in programs relevant to their surrounding economies, the potential ramifications we have specified would be nullified. However, we are skeptical that ten small and increasingly underfunded northern colleges and universities, if successfully driven to further specialization, will be able to cover the training needs of the Provincial North. The magnitude of such a task is significant, given that we are talking about 150 distinct municipalities, dispersed across a landmass comparable in size to Chile. Though typically conceptualized as a homogenous "other" (Coates, 1994; Halseth, et al., 2009), it is essential to remember that northern areas in Canada are quite diverse, both demographically and economically, spanning sectors such as agriculture, resource extraction (e.g., fishing, logging, mining, oil), tourism, and numerous others. This produces great variance in human capital needs, even among neighbouring towns. Besides, it is important to note that the human capital needs of these communities are dynamic, with industries falling and rising due to an array of factors. As such, even if northern $\mathrm{HE}$ organizations managed to perfectly align their needs with those of their surrounding communities, it is doubtful that they would be able to adapt to changing labour market needs.

Scenario 2 - Total HE System Exit

In a second plausible scenario, a student unable to enrol in an HE program locally may decide to forego further studies altogether, choosing to enter the workforce directly after high school graduation. This decision would inevitably channel them into a subset of low-skilled, poorly remunerated labour market segments, dramatically reducing their earning potential over the life course. Indeed, Statistics Canada reports show that the lifetime premium of gaining a university degree after a high school diplomarelative to obtaining no $\mathrm{HE}$ training-is approximately $\$ 728,000$ for men and $\$ 442,000$ for women (see Frenette, 2014). At the community level, system exit would also suppress human capital and skills development in the North, exacerbating regional human capital gaps that policy reports have repeatedly identified within Canada (e.g., Alasia, 2005; Alasia \& Magnusson, 2005; Magnusson \& Alasia, 2005). Indeed, our recent work using the Longitudinal International Study of Adults (LISA) has shown 
that there are significant disparities in the stock of literacy and numeracy skills possessed by urban residents and those in more-remote Canadian regions (Zarifa et al., 2019).

One rebuttal to this outlined scenario is that labour markets in northern regions have lower human capital demands and that by entirely bypassing $\mathrm{HE}$, students may be aligning their skill profiles with those of their surrounding communities. This reasoning is supported by the documented out-migration of skilled workers from rural to urban areas (Rothwell et al., 2002). Nevertheless, we would posit that, from an economic development standpoint, it is preferable for northern regions to have a surplus of highly skilled workers who migrate to urban areas than to have a shortage in the local availability of these individuals. One notable example of this is the commonly discussed shortage of physicians and health care professionals in northern communities (Komarnicki, 2012), although other examples exist in industrial sectors, such as mining (e.g., Skogstad \& Alahmar, 2016).

\section{Scenario 3-Out-Migration}

A third plausible scenario consists of those northern students who, within a more differentiated Ontario $\mathrm{HE}$ system, behave as expected by policy-makers by relocating to more-distant $\mathrm{HE}$ institutions specializing in their first-choice area of study. The odds of these students completing their programs are arguably reduced, in comparison to those who attend first-choice programs close to home, given the additional financial, social, and psychological challenges brought on by geographical relocation. Studies have found that when students move from remote rural regions to more-diverse urban environments, adapting to these new communities can generate much psychological stress (Matlzan, 2006). Their lack of experience in interacting with individuals from different cultures produces challenges in adapting to cosmopolitan urban environments (Ganss, 2016). At the community level, this outlined scenario also has the additional disadvantage of incentivizing out-migration from northern regions and exacerbating traditional northern-southern "brain drains" in Canada (Clemenson \& Pitbaldo, 2007). Indeed, studies across numerous jurisdictions show that out-migration for educational purposes is often irreversible, with migrants remaining in areas proximate to their universities after graduation (e.g., Bjarnason \& Edvardsson, 2017). 


\section{Discussion}

It is challenging to identify which benefits, if any, differentiation policies will offer Northern Ontario communities and their residents. By driving greater institutional specialization in pre-existing areas of strength, and increasing the already long distances that some northern students must travel to enrol in $\mathrm{HE}$ institutions, differentiation has the potential to exacerbate the barriers that many residents already face on the path to educational attainment. As we have outlined above, through impacting educational achievement at the individual level, differentiation policies may also hamper regional human capital development and, thus, the economic prosperity of northern communities. It is therefore vital to contemplate two questions in light of these projections. First, what are some sensible strategies to mitigate the effects of differentiation on northern communities? Second, how can we make sense of the development and existence of differentiation policies, given their potential to harm northern communities? We provide preliminary answers to both of these questions below, which we hope will spark further inquiry and theorizing in this space.

\section{Strategies to Mitigate the Impact of Differentiation}

The provincial government's longstanding commitment to, and investment in, differentiation policy makes it more productive to think about policies that can complement differentiation rather than replace it. To that end, we outline several strategies that could potentially mitigate the impact of a more differentiated HE system on Northern Ontario communities. One evident and cost-sensitive option would be to bolster the existing distance education options offered by multiple organizations. Most notably, Contact North, an initiative funded by the Ontario Ministry of Training, Colleges, and Universities (MTCU), has operated in this space since 1986. At the time of writing, it claimed to serve over 600 remote and rural communities across the province, via learning centres that provide access to hardware, software, and high-speed internet. Rather than providing its own programming, Contact North serves as an access point for courses offered by the province's school boards, public colleges and universities, Indigenous institutes, and other skill providers. A second organization, OntarioLearn, provides access to over a thousand online courses and 550 programs offered by public colleges. It is tailored for non-traditional and mature students, providing over a dozen start dates per year, flexible completion timelines, 
and technical support. A third provincially-funded organization, eCampus Ontario, also curates a collection of complementary open textbooks and other digital resources that align with in-demand subject areas in the province. Through additional funding and greater coordination, this digital learning infrastructure in Ontario could be extended to even more communities across the Provincial North, to counteract the heightened effects of distance deterrence prompted by differentiation.

Of course, the recommendation provided above is not without its drawbacks or difficulties given that the digital skills required to participate in distance education are not randomly distributed. As such, it is imperative that infrastructure investments be complemented by programs to improve digital literacy. It is also important to promote technology use across moreremote regions, given that individuals in such areas may have a stronger aversion to technology adoption, even when accounting for demographics (McKeown et al., 2007). Nevertheless, bolstering initiatives, such as Contact North, OntarioLearn, and eCampus Ontario, could serve as a valuable strategy to bring $\mathrm{HE}$ closer to the Provincial North.

\section{Urban-Bias in HE policy}

One potential explanation for the existence of differentiation policy, in light of its prospective adverse effects on northern communities, is that $\mathrm{HE}$ policy-making has an urban bias. This is a general argument that has been made repeatedly by educational researchers (Corbett, 2001; 2014; Weller \& Rosehart, 1985), and social scientists more broadly (Coates, 1994; Coates et al., 2014), both in Canada and abroad. Coates \& Poelzer (2014), for example, argue that much of the Provincial North in Canada continues to experience a high degree of political marginalization, being governed by politicians situated in southern capitals. These individuals often lack first-hand knowledge of socio-economic problems in the North and have traditionally operated based on erroneous abstractions about the northern "hinterland" (Coates, 1994). This dynamic encourages the creation of government policies that are engineered to work, or have worked, within urban communities in southern Canada, and which are often implemented in remote northern regions with little thought given to their unintended effects. Several notable examples of this are available throughout education history, though for the sake of brevity we only outline one prominent example below. 
Most famously, Bowles \& Gintis (1976) have argued that the structure of compulsory $\mathrm{K}-12$ schooling in the nineteenth century mirrored the needs of industrializing North American urban centres. They note that it was generally unwelcomed in more-remote and rural communities, given that it negated children's traditional participation in, and contributions to, the family through farming, fishing, and other productive activities. These inconsistencies between the structure of modern $\mathrm{K}-12$ schooling and rural lifestyles prompted considerable resistance (Corbett, 2001).Indeed, Corbett $(2009 ; 2014)$ argues that echoes of anti-schooling sentiments remained strong in remote regions in Canada well into the twentieth century, noting that the idea that someone would complete high school remained only weakly institutionalized until its closing decades. From the standpoint of this vast literature indicating the mismatch between education policy and the interests of remote communities, the differentiation policies we have explored through this piece can be seen as part of a broader pattern of systems engineered to meet the needs of southern urban communities.

\section{Conclusion}

Differentiation policies have been strongly championed in Ontario since 2005, as a lever to improve the quality of $\mathrm{HE}$ without increasing budget expenditures. More than a decade later, little has emerged in the form of an academic critique of how this policy may adversely affect traditionally marginalized groups, including the residents of northern communities. Through this piece, we draw on the distance deterrence literature and well-established facts within it to demonstrate how, through promoting institutional specialization, differentiation policies may unintentionally harm educational attainment in northern communities. We outline several possible scenarios that northern students may find themselves in, and how these scenarios may impact both the students' trajectories and communitylevel outcomes. Moreover, we outline strategies to mitigate the effects of differentiation, along with a theoretical frame through which to understand the existence of differentiation policy within a northern context. We hope that this article sparks further interest in, and reflection upon, the disparate and unintended effects of differentiation policies in Ontario and other jurisdictions. In particular, we believe that there is a need to consider these policy developments and their likely consequences for historically marginalized groups within the North, especially Indigenous communities 
that face additional barriers on their path to participating in $\mathrm{HE}$ and achieving economic prosperity. Perhaps most importantly, there should be an effort to rigorously monitor the ongoing impact of differentiation policies on participation rates among these groups, particularly if the current provincial government in Ontario is successful in motivating colleges and universities to differentiate through performance-based funding schemes.

\section{Notes}

1. For other commentaries on differentiation from this time period, see Clark et al. (2009; 2011), whose popular books argued that it would be prudent for the province to use funding formulas to develop incentives for colleges and universities to specialize in contrasting programmatic areas and types of activities. They also advanced a series of other complementary reforms (e.g. an Open University, teaching-intensive universities).

2. As van Vught (2008) notes, better alignment with the labour market needs is commonly cited as a key advantage of differentiated systems over homogenous counterparts, given that the greater capacity of the former to be responsive to the diverse skills demands of complex economies.

3. Though attracting less public attention during this period, there has also been some thoughtful academic analysis of differentiation, and its drivers, within the Ontario university sector (Piché, 2015; 2015a)

4. Sainos (2017) notes that the institutional specialization brought on by differentiation could prompt pockets of "elitism" and exclusivity across the Ontario HE system, but does not elaborate on the spatial or geographical dimensions of this process.

5. Colleges include: Boreal (Sudbury), Cambrian (Sudbury), Canadore (North Bay), Confederation (Thunder Bay), Northern (Timmis) and Sault (Sault Ste. Marie). Universities include: Algoma (Sault Ste. Marie), Laurentian (Sudbury), Lakehead (Thunder Bay), Nipissing (North Bay).

6. For example, OCAD University, Ryerson University and the University of Toronto are all within a 15-minute walk from each other.

7. Of course, there are many other factors at play here. However, a focus on these elementary factors helps to focus our analysis and discussion of potential individual and community impacts.

8. Our examples here are not designed to repeat conventional narratives of professional or vocational fields as being superior to conventional disciplinary programs. In most cases, it is possible to reverse the ordering of fields without distorting the relevance of our statements. 
9. A second type of within-system adaptation would consist of a lateral shift into programs for which they are not ideally suited, based on their own self-assessments of competence or subject-matter interest. For example, a student whose primary strength is their reading comprehension and writing ability may be driven into quantitative fields in the sciences (e.g. physics) for which they do not possess the aptitude nor intellectual curiosity. The opposite is also possible, with students who excel in mathematics being driven into literary fields (e.g. English). This dynamic could, in turn, reduce the odds that they will successfully complete their second-choice program.

\section{References}

Agasisti, T., \& Dal Bianco, A. (2011). Determinants of college student migration in Italy: Empirical evidence from a gravity Approach. SSRN Electronic Journal. https://doi.org/10.2139/ssrn.1063481

Alasia, A. (2005). Skills, innovation and growth: Key issues for rural and territorial development: A survey of the literature. Statistics Canada.

Alasia, A., \& Magnusson, E. (2005). Occupational skill level: The divide between rural and urban Canada. Rural and Small Town Canada Analysis Bulletin, 6(2), 1-30.

Alm, J., \&Winters, J. V. (2009). Distance and intrastate college student migration. Economics of Education Review, 28(6), 728-738. https://doi.org/10.1016/j. econedurev.2009.06.008

Alon, S., \& DiPrete, T. A. (2015). Gender differences in the formation of a field of study choice set. Sociological Science, 2, 50-81. https://doi.org/10.15195/v2.a5

Arcidiacono, P., Hotz, V. J., \& Kang, S. (2012). Modeling college major choices using elicited measures of expectations and counterfactuals. Journal of Econometrics, 166(1), 3-16. https://doi.org/10.1016/j.jeconom.2011.06.002

Auld, D., \& Coates, K. (2018). Performance anxiety Part II: How to ensure postsecondary institutions deliver on the expectations of students, parents, employers and governments. Macdonald Laurier Institute. http://macdonaldlaurier.ca/ files/pdf/MLI PSE PartII FWeb.pdf

Barcus, H.R., \& Brunn, S.D. (2009). Towards a typology of mobility and place attachment in rural America. Journal of Appalachian Studies, 15(1/2), 26-48.

Barcus, H.R., \& Brunn, S.D. (2010). Place elasticity: Exploring a new conceptualization of mobility and place attachment in rural America. Geografiska Annaler: Series B, Human Geography, 92(4), 281-295. https://doi. org/10.1111/j.1468-0467.2010.00353.x 
Bastedo, M.N., \& Gumport, P.J. (2003). Access to what? Mission differentiation and academic stratification in U.S. public higher education. Higher Education, 46(3), 341-359. https://doi.org/10.1023/A:1025374011204

Bjarnason, T., \& Edvardsson, I.R. (2017). University pathways of urban and rural migration in Iceland. Journal of Rural Studies, 54, 244-254. https://doi. org/10.1016/j.jrurstud.2017.07.001

Boudon, R. (2016). The unintended consequences of social action. The Unintended Consequences of Social Action. The McMillan Press Ltd. https://doi. org/10.1007/978-1-349-04381-1

Bowles, S., \& Gintis, H. (1976). Schooling in capitalist America. Basic Books.

Cameron, D.M. (2005). Ontario's Rae Report: Investing in growth. Canadian Public Administration/Administration Publique Du Canada, 48(2), 280-287. https://doi.org/10.1111/j.1754-7121.2005.tb02193.x

Canadian Federation of Students - Ontario. (2017). Issues policy. https://www. cfsontario.ca/wp-content/uploads/2018/10/Issues-Policy-2017.01.pdf

Clark, I.D., \& Trick, D. (2006). Advising for impact: Lessons from the Rae review on the use of special-purpose advisory commissions. Canadian Public Administration/Administration Publique Du Canada, 49(2), 180-195. https:// doi.org/10.1111/j.1754-7121.2006.tb01978.x

Clark, I., Moran, G., Skolnik, M., \& Trick, D. (2009). Academic transformation: The forces reshaping higher education in Ontario. McGill-Queen's University Press.

Clark, I., Trick, D., \& Van Loon, R. (2011). Academic Reform: Policy Options for Improving the Quality and Cost-Effectiveness of Undergraduate Education in Ontario. McGill-Queen's University Press.

Clemenson, H., \& Pitblado, R. (2007). Recent Trends in Rural-Urban Migration. Our Diverse Cities, 3(Summer), 25-29. http://canada.metropolis.net/pdfs/ ODC Summer07 3 en.pdf\#page=27

Cloodt, D., Cörvers, F., Heijke, H., \& Thor, J. Van. (2010). The impact of distance deterrence on the choice of field of study in vocational education in the Netherlands. Investigaciones de Economia de La Educación, 5, 605-624.

Coates, K. (1994). The rediscovery of the North: Towards a conceptual framework for the study of northern/remote regions. Northern Review, 12/13, 15-43.

Coates, K., Holroyd, C., \& Leader, J. (2014). Managing the forgotten north: Governance structures and administrative operations of Canada's provincial norths. Northern Review, 38, 6-54. https://thenorthernreview.ca/index.php/ nr/article/view/324

Coates, K., \& Poelzer, G. (2014). The Next Northern Challenge: The Reality of the ProvincialNorth.Macdonald Laurier Institute.https://www.macdonaldlaurier. ca/files/pdf/MLITheProvincialNorth04-14-Final.pdf 
Corbett, M. (2001). A protracted struggle: Rural resistance and normalization in Canadian educational history. Historial Studies in Education, 13(1), 19-48.

Corbett, M. (2005). Rural education and out-migration: The case of a coastal community. Canadian Journal of Education, 28(1), 52-72.

Corbett, M. (2009). Rural schooling in mobile modernity: Returning to the places I've been. Journal of Research in Rural Education, 24(7), 1-13.

Corbett, M. (2014). We have never been urban: Modernization, small schools, and resilient rurality in Atlantic Canada. Journal of Rural and Community Development, 9(3), 186-202.

Cullinan, J., Flannery, D., Walsh, S., \& McCoy, S. (2013). Distance effects, social class and the decision to participate in higher education in Ireland. Economic and Social Review, 44(1), 19-51.

Dickerson, A., \& McIntosh, S. (2013). The impact of distance to nearest education institution on the post-compulsory education participation decision. Urban Studies, 50(4), 742-758. https://doi.org/10.1177/0042098012455717

Fallis, G. (2013). Rethinking Higher Education: Participation, Research, and Differentiation. McGill-Queen's University Press.

Flannery, D., \& Cullinan, J. (2013). Where they go, what they do and why it matters: The importance of geographic accessibility and social class for decisions relating to higher education institution type, degree level and field of study. Applied Economics, 46(24), 2952-2965.

Frenette, M. (2004). Access to college and university: Does distance to school matter? Canadian Public Policy, 30(4), 426-443.

Frenette,M. (2006). Too far to go on? Distance to school and university participation. EducationEconomics,14(1),31-58.https://doi.org/10.1080/09645290500481865

Frenette, M. (2009). Do universities benefit local youth? Evidence from the creation of new universities. Economics of Education Review, 28(3), 318-328. https://doi.org/10.1016/j.econedurev.2008.04.004

Frenette, M. (2014). An investment of a lifetime? The long-term labour market premiums associated with a postsecondary education. https://www150.statcan. gc.ca/n1/pub/11f0019m/11f0019m2014359-eng.htm

Ganss, K.M. (2016). The college transition for first-year students from rural Oregon communities. Journal of Student Affairs Research and Practice, 53(3), 269-280. https://doi.org/10.1080/19496591.2016.1157487

Gibbons, S., \& Vignoles, A. (2012). Geography, choice and participation in higher education in England. Regional Science and Urban Economics, 42 (1-2), 98-113. https://doi.org/10.1016/j.regsciurbeco.2011.07.004 
Gill, T., Vidal Rodeiro, C., \& Zanini, N. (2018). Higher education choices of secondary school graduates with a Science, Technology, Engineering or Mathematics (STEM) background. Journal of Further and Higher Education, 42(7), 998-1014. https://doi.org/10.1080/0309877X.2017.1332358

Government of Canada. (2018). Prosperity and growth strategy for Northern Ontario. http://fednor.gc.ca/eic/site/fednor-fednor.nsf/eng/fn04481.html

Grossmann, V., Osikominu, A., \& Osterfeld, M. (2015). Are sociocultural factors important for studying a science university major? IZA Discussion Paper, (9415).

Haartsen, T., \& Stockdale, A. (2018). S/elective belonging: How rural newcomer families with children become stayers. In Population, Space and Place, 24(4). https://doi.org/10.1002/psp.2137

Halseth, G., Markey, S., Reimer, B., \& Mason, D. (2009). Introduction: The next rural economies. In G. Halseth, S. Markey, \& D. Bruce (Eds.), The next rural economies: Constructing rural place in global economies (pp. 1-16). CAB International.

Hango, D., Zarifa, D., Pizarro Milian, R. \& B. Seward (2019). Roots and STEMS? Examining field of study choices among northern and rural youth in Canada. Studies in Higher Education, https://doi.org/10.1080/03075079.2019.1643308

Hicks, M., \& Jonker, L. (2016). The differentiation of the Ontario university system: Where are we now and where should we go? http://www.heqco.ca/ SiteCollectionDocuments/Report-The-Differentiation-of-the-OntarioUniversity-System.pdf

Hicks, M., Wingarten, H., Jonker, L., \& Liu, S. (2013). The diversity of Ontario's colleges: $A$ dataset to inform the differentiation. http://www.heqco.ca/ SiteCollectionDocuments/College Differentiation Report.pdf

Huismarr, J., \& Morphew, C.C. (1998). Centralization and diversity: Evaluating the effects of government policies in U.S.A. and Dutch higher education. Higher Education Policy, 11(1), 3-13. https://doi.org/10.1016/ S0952-8733(97)00023-8

Jepsen, C., \& Montgomery, M. (2009). Miles to go before I learn: The effect of travel distance on the mature person's choice of a community college. Journal of Urban Economics, 65(1), 64-73. https://doi.org/10.1016/j.jue.2008.08.004

Jones, G., \& Skolnik, M. (2009). Degrees of opportunity broadening student access by increasing institutional differentiation in Ontario higher education. http://www. heqco.ca/SiteCollectionDocuments/Degrees of Opportunity.pdf

Kariel, H. G. (1968). Student enrollment and spatial interaction. The Annals of Regional Science, 2(1), 114-127. https://doi.org/10.1007/BF02096181 
Kaufman, A., Jonker, L., \& Hicks, M. (2016). The sustainability of the Ontario public postsecondary system: Putting together the pieces of the puzzle. http://www.heqco. ca/SiteCollectionDocuments/Formatted Capstone paper.pdf

Kim,Y.,Huang,J.,Sherraden,M.,\&Clancy,M.(2018).Child developmentaccounts and saving for college: Mediated by parental educational expectations? Social Science Quarterly, 99(3), 1105-1118. https://doi.org/10.1111/ssqu.12479

Kjellström, C., \& Regnér, H. (1999). The effects of geographical distance on the decision to enrol in university education. Scandinavian Journal of Educational Research, 43(4), 335-348. https://doi.org/10.1080/0031383990430401

Kloep, M., Hendry, L. B., Glendinning, A., Jan-Erik, I., \& Geir, A. E. (2003). peripheral visions? A cross-cultural study of rural youths' views on migration. Children's Geographies. https://doi.org/10.1080/14733280302189

Komarnicki, E. (2012). Labour and skills shortages in Canada: Addressing current and future challenges. https://www.canada.ca/content/dam/canada/employmentsocial-development/migration/documents/content/hoc/committee/411/ huma/reports/rp5937523/humarp09/humarp09-e.pdf

Kyung, W. (1996). In-migration of college students to the State of New York. The Journal of Higher Education, 67(3), 349-358. https://doi.org/10.1080/002215 $\underline{46.1996 .11780264}$

Lee, S., Hanna, S., \& Siregar, M. (1997). Children's college as a saving goal. Journal of Financial Counseling and Planning, 8(1), 33-36.

Lennon, M. C., Skolnik, M., \& Jones, G. (2015). The Rae Report in retrospect: https://www.oise.utoronto.ca/hec/UserFiles/File/Research/Papers/Rae Report in Retrospect.pdf

Leppel, K. (1993). Logit estimation of a gravity model of the college enrollment decision. Research in Higher Education, 34(3), 387-398. https://doi. org/10.1007/BF00991851

Magnusson, E., \& Alasia, A. (2004). Occupational patterns within industry groups: A rural-urban comparison. Rural and Small Town Canada Analysis Bulletin, 5(6), 2-16.

Maltzan, T. (2016). Rurality and higher education: Implications for identity and persistence. Ohio State University. http://rave.ohiolink.edu/etdc/ view?acc num $=0$ su1149275308

Mchugh, R., \& Morgan, J. N. (1984). The determinants of interstate student migration: A place-to-place analysis. Economics of Education Review, 3(4), 269-278. https://doi.org/10.1016/0272-7757(84)90045-1

Merton, R. K. (1936). The unanticipated consequences of purposive social action. American Sociological Review, 1(6), 894-904. https://doi.org/10.2307/2084615 
Michael N. Bastedo. (2008). Convergent institutional logics in public higher education: State policymaking and governing board activism. The Review of Higher Education, 32(2), 209-234. https://doi.org/10.1353/rhe.0.0045

Newbold, K.B., \& Brown, W.M. (2015). The urban-rural gap in university attendance: Determinants of university participation among Canadian youth. Journal of Regional Science, 55(4), 585-608. https://doi.org/10.1111/ jors. 12197

Ontario Confederation of University Faculty Associations. (2017). Differentiation policy framework for postsecondary education OCUFA analysis. https://ocufa. on.ca/assets/Differentiation-Policy-Framework-Analysis-FINAL.pdf

Ontario Graduate Students' Alliance. (2015). Response to the university funding model reform consultation discussion paper. https://uwaterloo.ca/graduatestudent-association/sites/ca.graduate-student-association/files/uploads/files/ ogsa submission to funding reform consultation.pdf

Ontario Public Service Employees Union. (2016). Funding the Future: Key recommendations for an evolving college system. https://opseu.org/information/ funding-future-key-recommendations-evolving-college-system

Ontario Undergraduate Student Alliance. (2016). Rural \& northern students. https://d3n8a8pro7vhmx.cloudfront.net/ousa/pages/88/attachments/ original/1479238557/Rural and Northern Students document. pdf?1479238557

Parker, P. D., Jerrim, J., Anders, J., \& Astell-Burt, T. (2016). Does living closer to a university increase educational attainment? A longitudinal study of aspirations, university entry, and elite university enrolment of Australian youth. Journal of Youth and Adolescence, 45(6), 1156-1175. https://doi. org/10.1007/s10964-015-0386-x

Piché,Pierre G, \& Jones, G.A.(2016). Institutional diversity in Ontario's university sector: A policy debate Analysis. Canadian Journal of Higher Education, 46(3), $1-17$.

Piché,Pierre Gilles.(2014). Systemic and climate diversity in Ontario'suniversitysector. University of Toronto. https://tspace.library.utoronto.ca/handle/1807/65718

Piché, Pierre Gilles. (2015a). Institutional diversity and funding universities in Ontario: Is there a link? Journal of Higher Education Policy and Management, 37(1), 52-68. https://doi.org/10.1080/1360080X.2014.991537

Piché, Pierre Gilles. (2015b). Measuring systemic and climate diversity in Ontario's university sector. Canadian Journal of Higher Education, 45(4), 63-80.

Pigini, C., \& Staffolani, S. (2016). Beyond participation: Do the cost and quality of higher education shape the enrollment composition? The case of Italy. Higher Education, 71(1), 119-142. https://doi.org/10.1007/s10734-015-9892-8 
Pizarro Milian, R. P., Davies, S., \& Zarifa, D. (2016). Barriers to differentiation: Applying organizational studies to Ontario higher education. Canadian Journal of Higher Education, 46(1), 19-37.

Pizarro Milian, R. (2018). Differentiating universities: Some insights from organization studies. Policy Reviews in Higher Education, 2(1), 79-104.

Pringle, J., \& Huisman, J. (2011). Understanding universities in Ontario, Canada: An industry analysis using Porter's Five Forces Framework. Canadian Journal of Higher Education, 41(3), 36-58. http://ezproxy.ace.edu/login?url=http:// search.ebscohost.com/login.aspx?direct=true\&AuthType=ip,uid\&db=eric $\underline{\& A N=E J 959453 \& s i t e=e d s-l i v e \& s c o p e=s i t e \% 5 C n h t t p: / / o j s . l i b r a r y . u b c . c a /}$ index.php/cjhe/article/view/36/2305

Rae, B. (n.d.). Ontario: A leader in learning. https://www.collegesontario.org/ research/research reports/EXT RAE REPORT.pdf

Robinson, D. (2015). Revolution or devolution?: How Northern Ontario should be governed. Thunder Bay, ON.

Rothwell, N., Bollman, R., Tremblay, J., \& Marshall, J. (2002). Migration to and from rural and small town Canada. Rural and Small Town Canada Analysis Bulletin, 3(6), 1-24.

Ruiz, M. E. (2007). Familismo and filial piety among Latino and Asian elders: Reevaluating family and social support. Hispanic Health Care International, 5(2), 81-89. https://doi.org/10.1891/154041507780978897

Rural Ontario Institute. (2017). Rural Ontario's Demography: Census Update 2016. http:/www.ruralontarioinstitute.ca/uploads/userfiles/files/Rural Ontario's Demography Census Update 2016.pdf

Ruth, T. (2009). College proximity: Mapping access to opportunity. Sociology of Education, 82(2), 126-146.

Sá,C.,Florax,R.J.G.M.,\&Rietveld,P.(2004).Determinants of the regionaldemand for higher education in the Netherlands: A gravity model approach. Regional Studies, 38(4), 375-392. https://doi.org/10.1080/03434002000213905

Sá, C., Florax, R. J. G. M., \& Rietveld, P. (2006). Does accessibility to higher education matter? Choice behaviour of high school graduates in the Netherlands. Spatial Economic Analysis, 1(2), 155-174. https://doi. org/10.1080/17421770601009791

Skogstad, K., \& Alahmar, A. (2016). The mining industry in Northwestern Ontario: An analysis of recent developments. https://www.lakeheadu.ca/sites/default/ files/uploads/3123/The Mining Industry in Northwestern Ontario sm.pdf 
Skolnik,M.L.(2013). An historical perspective on the idea of institutional diversity and differentiation in Ontario higher education. The College Quarterly, 16(2). http://www.collegequarterly.ca/2013-vol16-num01-winter/huang-capps. $\underline{\mathrm{html}}$

Smith-Morris, C., Morales-Campos, D., Alvarez, E. A. C., \& Turner, M. (2013). An anthropology of familismo. Hispanic Journal of Behavioral Sciences, 35(1), 35-60. https://doi.org/10.1177/0739986312459508

Sörlin, S. (2007). Funding diversity: Performance-based funding regimes as drivers of differentiation in higher education systems. Higher Education Policy, 20(4), 413-440. https://doi.org/10.1057/palgrave.hep.8300165

Spiess, C. K., \& Wrohlich, K. (2010). Does distance determine who attends a university in Germany? Economics of Education Review, 29(3), 470-479. https://doi.org/10.1016/j.econedurev.2009.10.009

Suhonen, T. (2014). Field-of-Study Choice in Higher Education: Does Distance Matter? Spatial Economic Analysis, 9(4), 355-375. https://doi.org/10.1080/1 7421772.2014.961533

Terry Long, B. (2004). How have college decisions changed over time? An application of the conditional logistic choice model. Journal of Econometrics, 121(1-2), 271-296. https://doi.org/10.1016/j.jeconom.2003.10.004

Trick, D. (2015). Affliated and federated universities as sources of university differentiation. http://www.heqco.ca/SiteCollectionDocuments/Affiliated and_Federated_Universities.pdf

Ullis, J. J., \& Knowles, P. L. (1975). A study of the intrastate migration of Washington college freshmen: A further test of the gravity model. The Annals of Regional Science, 9(1), 112-121. https://doi.org/10.1007/BF01284992

van Vught, F. (2008). Mission diversity and reputation in higher education. Higher Education Policy. https://doi.org/10.1057/hep.2008.5

Weingarten, H., \& Deller, F. (2010). The benefits of greater differentiation of Ontario's university sector. Toronto, $\mathrm{ON}$.

Weingarten, H., Hicks, M., Jonker, L., \& Liu, S. (2013). The diversity of Ontario's Universities: $A$ dataset to inform the differentiation discussion. http://www. heqco.ca/SiteCollectionDocuments/HEQCO Diversity ENG.pdf

Weller, G., \& Rosehart, R. (1985). Universities, politics and development in Northern Ontario and Northern Sweden: A comparative analysis. Canadian Journal of Higher Education, 15(3), 51-72.

Wiswall, M., \& Zafar, B. (2015). How do college students respond to public information about earnings? Journal of Human Capital, 9(2), 117-169. https:// doi.org/10.1086/681542 
Young, S., Piché, P. G., \& Jones, G. (2017). Two Towers of Transformation: The Compatibility of Policy Goals of Differentiation and Student Mobility. https:// www.oise.utoronto.ca/cihe/wp-content/uploads/sites/23/2016/10/TwoTowers-of-Transformation.pdf

Zarifa, D., Hango, D., \& Pizarro Milian, R. (2018). Proximity, prosperity, and participation: Examining access to postsecondary education among youth in Canada's Provincial North. Rural Sociology, 83(2), 270-314.

Zarifa, D., Seward, B., \& Milian, R. P. (2019). Location, location, location: Examining the rural-urban skills gap in Canada. Journal of Rural Studies, 72, $252-263$.

\section{Authors}

Roger Pizarro Milian is a visiting researcher in the Department of Leadership, Higher \& Adult Education at the University of Toronto.

Brad Seward is the Practice Lead for the research initiative Education and Skills at the Mowat Centre, Munk School for Public Policy, University of Toronto.

David Zarifa is professor in the Department of Sociology and Anthropology, and Canada Research Chair (Tier II) in Life Course Transitions in Northern and Rural Communities at Nipissing University in North Bay, Ontario. 